\title{
Exploring an activist approach of working with boys from socially vulnerable backgrounds in a sport context
}

Carla Luguetti ${ }^{\mathrm{a}^{*}}$, Kimberly L. Oliver ${ }^{\mathrm{b}}$, David Kirk ${ }^{\mathrm{c}}$ and Luiz Dantas ${ }^{\mathrm{a}}$

${ }^{a}$ School of Physical Education and Sport, University of Sao Paulo, Sao Paulo, Brazil.

${ }^{b}$ Department of Kinesiology and Dance, New Mexico State University, United States;

${ }^{c}$ School of Education, University of Strathclyde, United Kingdom.

Carla Luguetti

Department of Pedagogy of Human Movement. Av. Prof. Mello Moraes, 65 - Cidade Universitária, CEP: 05508-030 - São Paulo - SP

$+55(13) 981700505$

Email: luguetti@usp.br

Kimberly L. Oliver

Department of Kinesiology and Dance, New Mexico State University, United States P.O. Box 30001 MSC 3M, New Mexico State University, Las Cruces, NM 88003 575-646-4074

Email: koliver@nmsu.edu

David Kirk

School of Education, University of Strathclyde, United Kingdom. Lord Hope Building. 141 St James Road, Glasgow, G4 0LT

$+44(0) 1414448038$

Email: david.kirk@strath.ac.uk

Luiz Eduardo Pinto Basto Tourinho Dantas

Department of Pedagogy of Human Movement. Av. Prof. Mello Moraes, 65 - Cidade Universitária, CEP: 05508-030 - São Paulo - SP

$+55(11) 30913171$

Email: ldantas@usp.br

\footnotetext{
* Corresponding author. School of Physical Education and Sport, Department of Pedagogy of Human Movement, University of Sao Paulo, Sao Paulo, Brazil. Av. Prof. Mello Moraes, 65 - Cidade Universitária, CEP: 05508-030 - São Paulo - SP. Email: luguetti@usp.br
} 


\title{
Exploring an activist approach of working with boys from socially vulnerable backgrounds in a sport context
}

\begin{abstract}
This study explores an activist approach for co-creating a prototype pedagogical model of sport for working with boys from socially vulnerable backgrounds. This paper addresses the key features that emerged when we identified what facilitated and hindered the boys' engagement in sport. This study was an activist research project that was conducted between July 2013 and December 2013 in a soccer program in a socially and economically disadvantaged neighborhood in Brazil. The lead author, supervised by the second author, worked with a soccer class of 17 boys between ages 13 and 15, 4 coaches, a pedagogical coordinator and a social worker. Multiple sources of data were collected, including 38 field journal/observations and audio records of: 18 youth work sessions, 16 coaches' work sessions, and 3 combined coaches and youth work sessions. In addition the first and second author had 3690 minute debriefing and planning sessions. By using an activist approach three features were identified as being essential: an ethic of care, an attentiveness to the community, and a community of sport. Findings suggest that it is possible to use sport as a cultural asset to benefit youth from socially vulnerable backgrounds by offering them a place where they can feel protected and dream about possible futures.
\end{abstract}

Keywords: Student-centered pedagogy; Activist research; Social vulnerability; Empowerment; Participatory action research; Boys; Activist scholars; Critical pedagogy; Paulo Freire; Marginalized groups;

Over the past two decades activist scholars in physical education and sport pedagogy have engaged in research with the intent to challenge and transform barriers to young people's engagement in physical activity and physical education (Enright \& O’Sullivan, 2010; Fisette \& Walton, 2014; Oliver \& Kirk, 2014). Activist scholars work from the belief that knowledge is rooted in social relations and is more powerful when produced collaboratively through action (Cammarota \& Fine, 2008; Freire, 1987, 1996). In physical education, some studies have investigated physical activity experiences of youth from socially vulnerable backgrounds (Burnett, 2013; Lawson, 2005; McEvoy, MacPhail, \& Enright, 2015; Smyth, Mooney, \& Casey, 2011), but few studies have 
proposed to explore an activist way of working with this kind of population. The majority of activist studies, however, have been done with girls in physical education contexts (Fisette \& Walton, 2014; Oliver \& Kirk, 2014; Oliver, 2001). Building on this work, in this paper we explore the use of an activist approach for working with boys from socially vulnerable backgrounds in a sport context.

Problematic to traditional views of youth from socially vulnerable backgrounds is the belief that any problem (poverty educational failure, drug alcohol abuse, etc.) faced by these youth is a result mainly of their own volition. Thus we blame the victim for the victim's problems (Fitzpatrick, 2013). We have chosen an activist approach to working with boys from socially vulnerable backgrounds because rather than blame the victim, we assert that young people have the capability to analyze their social context and to challenge and resist the forces that impede their possibilities for liberation (Freire, 1987, 1996).

This paper is part of a larger two-phase activist research study (Fine, 2007) that aimed to co-create a prototype pedagogical model of sport for working with boys from socially vulnerable backgrounds. In this paper, we highlight phase one of the research project, 'Building the Foundation' (Oliver \& Oesterreich, 2013). We worked with 17 boys, 4 coaches, 1 pedagogical coordinator, and 1 social worker that were part of a soccer program designed for youth in a socially and economically disadvantaged neighborhood in Brazil. This phase of the research was designed with the intent of identifying what facilitated and hindered the boys' engagement in sport.

We used an activist approach, Student-Centered Inquiry as Curriculum (Oliver $\&$ Oesterreich, 2013), as a way of co-creating the prototype pedagogical model. As we will elaborate later, this approach is designed to use inquiry-based learning centered in action in order to listen and respond to youth. ${ }^{\dagger}$ In what follows we first consider some of the foundational ideas in relation to sport-based interventions for socially vulnerable youth and the activist approach that informed the conduct of our fieldwork. Second, we provide a detailed account of this fieldwork. Third, we set out the three main themes that emerged from this work with youth from socially vulnerable backgrounds. We also consider the possibility that the three key features of the work expressed in the main

\footnotetext{
${ }^{\dagger}$ For a detailed description of Student-Centered Inquiry as Curriculum see Oliver \& Oesterreich, 2013 and Oliver and Oesterreich et al, 2015)
} 
themes might form the basis for co-creating a prototype pedagogical model, a notion we introduce in the next section.

\section{Sport-based interventions for socially vulnerable youth}

Social vulnerability can be defined as the result of the negative relationship between availability of material or symbolic resources and access to opportunity that is structurally, socially, economically and/or culturally provided by the state, market and society (Misztal 2011). The lack of access to education, work, healthcare, leisure and other forms of cultural capital decrease the chances of upward social mobility.

In Brazil, many children and youth live in socially vulnerable conditions in which they are exposed to negative influences such as drug trafficking, violence, family breakdown, poor health, and poverty (Fonseca, Sena, Santos, Dias, \& Costa, 2013). Living in an environment of social vulnerability is often a factor in what is socially constructed as 'negative behavior of youth,' including: anti-social behavior, teenage pregnancy, school drop-out, drug and alcohol abuse, obesity and self-harm (Abramovay, Castro, Pinheiro, Lima, \& Martinelli, 2002). It is suggested by Fonseca et al. (2013) that young people suffer from distorted relationships with the institutions of society, such as the family, school, labor market, healthcare and the social justice system.

Authors use a variety of names for socially vulnerable youth, such as; underserved youth (Hellison, 2000), disaffected youth (Sandford \& Duncombe, 2011), at-risk youth (Coalter, Allison, \& Taylor, 2000), and marginalized young people (Kelly, 2011) to name a few. However, these different terms may not represent the complexities of social issues because they tend to put the focus on the individual, rather than taking into account the wider social structures in which youth live (Haudenhuyse, Theeboom, \& Coalter, 2012). In this paper we use the term "youth from socially vulnerable backgrounds" because we do not want to "blame the youth". We believe that young people could be empowered in their social context to look for opportunities beyond their current situation (Fine, 2007; Freire, 1987, 1996). This would require a collective, mutual and contagious empowerment through education, action and reflection (Freire, 1987, 1996; Lawson, 2005). Such an approach would need to transcend a narrow focus 
on individuals' empowerment to target groups and entire communities, aiming to organize and mobilize them for collective action.

There is a growing interest in developing interventions to diminish problems arising from social vulnerability by offering access to social and cultural capital through music, sports, and literature (Fox \& Fine, 2013; Greene, 2000). Among the forms of social and cultural capital, sport is almost always addressed in the public policies of different countries (Coalter, 2005; Kirk, 2004; Vandermeerschen, Vos, \& Scheerder, 2013). There is a belief that sport can have a positive impact in socially vulnerable communities. However, despite the advocacy for sports as a means to overcome issues related to social vulnerability, there is a lack of evidence about the positive impact of sports in settings in which social vulnerability is prominent (Coalter, 2005).

Added to the lack of evidence, there are obstacles to the development of such sport programs. For example, what should these programs look like? Few programs designed for youth from socially vulnerable backgrounds align a theoretical basis with a pedagogical practice. In other words, there is a gap between curriculum policy formulation and actual practice (Spaaij \& Jeanes, 2012). Many programs show a reductive vision of sport, without attention to the broader structures in which the young people who play the sport live (Haudenhuyse et al., 2012). It might be argued that many sport-based interventions are technical, highlighting individual deficits and emphasizing structural inequalities (Spaaij \& Jeanes, 2012), as opposed to socially critical programs which aim to provoke social action and change (Cammarota \& Fine, 2008; McDonald, 2014; Fine, 2007). Further, few programs have been developed with either the participation of the young people or the community for which the program serves (Lawson, 2005).

Prior to data collection for this study, we read the literature on pedagogical models in sport and physical education to assist us in the design of this intervention (Casey, 2014; Kirk, 2013). We chose to use a Student-Centered Inquiry as Curriculum (Oliver \& Oesterreich, 2013) approach as a means of conducting the fieldwork because it's focus was student-centered inquiry centered in action, something we believed necessary if we were to co-create a prototype pedagogical model with the participants. While this paper is not about the development of such a prototype model, we think it is important to signal early in this paper that the key emergent features of the work reported here - an ethic of care, attentiveness to the community, and the fostering of a 
community of sport - may be essential to working with socially vulnerable youth and therefore may form the basis of the future development of a pedagogical model.

\section{An activist approach to working with youth}

An activist approach to working with youth challenges the conventional conception of youth as subordinate to the expert teacher in engaging with what is taught and how it is taught (Bovill, Cook-Sather, \& Felten, 2011; Cook-Sather, 2002). Activist research engages learners in order to create spaces in which youth will actively participate in their education and feel responsible for their own and others' learning (Cammarota \& Fine, 2008; Cochran-Smith \& Lytle, 2009). They feel empowered and motivated to participate constructively in their education because not only are their voices sought, but they are responded to (Cook-Sather, 2002).

Activist studies are prominent in feminist and critical pedagogy fields (e.g., Fine, 2007; Freire, 1987; 1996; Hill-Collins, 2000; Hooks, 2000; Shor, 1992) According to Freire, education is a "conscientization", and is defined as the process of becoming aware of the structural, political and cultural constraints that prevent a group or an individual from exercising autonomy or participating in a democratic society (Freire 1987). Freire's critical pedagogy of the oppressed aimed to empower both students and teachers to develop a critically conscious understanding of their relationship with the world (Freire 1987). In that sense pedagogy should connect learning to social change, a project that challenges students to critically engage with the world so they could act on it. This is reflective of activist research processes.

In general education, scholars have engaged in research that offers youth from socially vulnerable backgrounds empowering possibilities by using activist approaches in areas such as visual arts (Fox \& Fine, 2013; Greene, 2000; Petit, 2009), literature (Wright \& Mahiri, 2012), mathematics (Yang, 2009) or discussion groups in schools (Foster-Fishman et al., 2010; Fox \& Fine, 2013; Mcintyre, 2000; Mirra, Morrell, Cain, Scorza, \& Ford, 2013). In this kind of research youth participated in discussions on different topics based on their needs. In this sense, there is an established body of knowledge in relation to activist research in the general education which aims to create empowering possibilities for youth from socially vulnerable backgrounds. 
In the field of physical education, activist researchers have worked, primarily with girls to challenge their barriers to engagement in physical activity and physical education (Enright \& O’Sullivan, 2010, 2012; Fisette \& Walton, 2014; Oliver \& Kirk, 2014). This research offers pedagogical processes that assist girls in naming, critiquing, negotiating, and/or transforming barriers to their engagement in physical education and physical activity. Although we have observed an increase of activist research in general education and with girls in physical education, studies of sport programs have mainly focused on prescription and control of youth's behaviors (Lawson, 2005; Spaaij \& Jeanes, 2012). This dearth of activist work highlights the necessity to develop this approach with youth from socially vulnerable backgrounds in sport contexts.

\section{Methodology}

Setting and participants

This project took place in a soccer program in a socially and economically disadvantaged neighborhood in Santos, Brazil. According to the Brazilian government (SEADE, 2003, 2010), this neighborhood is considered a highly socially and economically disadvantaged area because there is low per capita household income, poor health condition and low quality of the education system. We start this section with a brief description of the context in order to paint a picture of where this study took place.

\section{The Sports Project Context-}

Lead author: I saw the last training session, and I want to talk to you. I have never seen a training session like that. It was so crazy...I counted at least 8 drug addicts on the soccer field. The field has a big wall, and the drug addicts sit on the wall and watch the game. They consume drugs while the boys are playing. It is happening in the open where everyone can see it! Suddenly, a drug dealer was coming in our direction. Coach Anthony and the boys were sitting in the middle of the field. This drug dealer came towards us and he looked at us. He signalled to greet Anthony, a kind of ok. I was really nervous and unprotected. I felt vulnerable and unable to defend the boys. Anthony responded to the drug dealer with the same sign.

Second author: What does that sign mean?

Lead author: I think it is in relation to power, something like "I know that you're here". I think the drug dealer was trying to show us who 
was in charge! A guy was completely drunk, whistling and calling for the end of the training session. "STOP, STOP," he was screaming. The training sessions were always crazy like this. Remember what happened last week? I saw two policemen come running onto the field carrying big guns. The Small kids were so afraid! It was the first time I'd seen this police approach. The coaches have talked about this, but I had never seen it. It was crazy how kids run everywhere. Everybody was afraid. The cops were shouting "GO, GO, GO!". The action of police was crazy!

Embedded within the above passage is the complexity of the environment with which this sport project existed. There were coaches and their teenaged boys, there were drug traffickers and drug users, there was a custodian of the field who was homeless and more often than not drunk during the training sessions, and there were the local police. This project took place in this 'shared' space and each of the groups has impacted in the functioning of the sport project in the local community.

The study included 17 boys between ages 13 and 15 . In relation to household income, $64.7 \%$ of the boys came from households that had either one or two minimum wage incomes and $35.3 \%$ from homes with less than one minimum wage income. The monthly minimum wage income in Brazil is \$810 BRL ( $\sim 355$ USD) and is considered one of the lowest in the world (Brasil, 2013). In addition to the boys, eight adults were also involved in the study: four coaches, a pedagogic coordinator, a social worker, and two researchers. The coaches were ex-athletes and had an average of 2 years and 9 months of experience in working in socially and economically disadvantaged areas.

Whereas the boys and coaches were insiders in this study, I (the lead author Carla), as the primary researcher, was an in-betweener /outsider (Anzaldúa, 2007; Collins, 2000). At the time of the study, I was 31 years old and identified as a $\mathrm{PhD}$ student, middle class and physically active as a recreational soccer player. Although my gender, race, age, and social class positioned me as an outsider, my experience in soccer and understanding of the socially vulnerable context positioned me as an inbetweener(Anzaldúa, 2007).

The second author (Kim) - an expert in student-centered pedagogy and inquirybased education centered in action- had roles in the study: a) peer debriefer; b) assisted with progressive data analysis; and c) helped in facilitating a collaborative construction of the youth's and coaches' work sessions that were built on the idea of inquiry oriented and student-centered ways of working. The third and fourth authors were involved with the conceptual work and the general design of the study. 
Data collection sources and data analyses

A Student-Centered Inquiry as Curriculum (SCIC) (Oliver \& Oesterreich, 2013) approach was used both as a process of working with the boys as well as serving as a framework for data collection. This approach combines student-centered pedagogy with inquiry-based education centered in action as an activist way of working with youth. It was originally designed as a way of developing curriculum with youth that better meet their interests, motivation and learning in physical education. Student-Centered Inquiry as Curriculum involves a two-phase process: Building the Foundation and a four-phase cyclical process of Planning, Responding to Students, Listening to Respond, and Analyzing Responses as a means of curriculum design and implementation (Figure 1).

[insert Figure].

In this project we used the SCIC approach a little differently. In the first phase of our project we Built the Foundation by using the four-phase cyclical process as a means of working with the youth and coaches in the work sessions. Building the Foundation was the first phase of this study and took place over an 8-week period of time. This phase aimed to co-create an environment that allowed for mutual understanding, respect, and learning amongst all participants involved in the setting (Oliver \& Oesterreich, 2013). In this phase, our main objective was to understand the boys (likes, dislikes, family, school, and community environments) as well as their perceptions about the training sessions, and their barriers and facilitators for engaging in the sport. We worked in a back and forth process every week between the coaches and the boys so that we could better understand each other.

We did this work by utilizing the cyclical process (Planning, Responding to students, Listening to responses, and Analyzing responses). Planning involved the creation of the work sessions between the boys and myself as well as the work sessions between the coaches and me. Responding to Students involved the creation of work sessions that bridged what I was learning from the boys, with what I was learning about using a student centered pedagogical approach with boys, and what I was doing with the coaches. Listening to Respond involved the debriefing and analysis of data between 
Kim and I. This took place the day after the work sessions with the boys. Analyzing the Responses involved the debriefing and analysis of data between Kim and I following the coaches' work sessions.

From what we learned in the first phase, Building the Foundation, we implemented in the second phase that was our activist piece. Here we co-created and implemented a Leadership Program that allowed the learning outcomes to emerge. We describe in this paper the Building the Foundation and how that served as our mechanism for understanding the key features that would make up our prototype pedagogical model.

As a means of co-creating a prototype pedagogical model for working with youth from socially vulnerable back grounds we collected data over an 18 week period of time. I (Carla) met with the boys for 40 minutes every Wednesday prior to their training sessions from July-December 2013 for a total of 18 work sessions. Following the boys work session I skyped for approximately 90 minutes with Kim during which time I debriefed, analyzed what I was learning, and planned for the upcoming coaches' work session. On Fridays I worked with the coaches, the pedagogical coordinator and the social worker for 1 hour for a total of 16 sessions. This was followed by another 90 minute Skype session with Kim whereby we debriefed, analyzed what I was learning, and planned for the upcoming youth work session. We also planned and held 3 coaches/youths work sessions together. We decided to meet coaches and youths separately in most sessions because this was an opportunity for the boys to work in a space where the coaches who held the power were not present.

We collected data from multiple sources, including 38 field journal/observations of the training sessions and audio records of all sessions: youths' work sessions (18), coaches' work sessions (16), combined coach and youth work sessions (3), and meetings between Carla and Kim (37). In all, we analysed 69 audiotapes (368 pages of transcriptions), 25 pages of field notes and student generated artefacts. Data analysis was ongoing throughout the project and the sessions with the youth, the coaches, and with the youth/coaches were based on what we were learning as we were going through the process.

The data was organized chronologically and filing it by session date. Professor Kim and I read all transcripts of our meetings. I, also, read all transcripts of the youth and coaches' work sessions, all field notes and student-generated artifacts. To enhance 
the data analysis, Kim and I met twice face-to-face to review our previous meetings. The first meeting (September 2013) occurred in the middle of data collection with our main objective to verify the emergence of the key features (Building the Foundation). Our next meeting (February 2014) aimed to identify the learning outcomes (activist piece - Leadership Program). In Building the Foundation the following categories emerged as key features: an ethic of care, an attentiveness to the community, and a community of sport. These will be described in the findings.

\section{Findings}

By using an activist approach that embedded student-centered pedagogy with an inquiry-based education centered in action we came to understand what facilitated and hindered the boys' engagement in sport. First, all involved in the project worked from an ethic of care. Second, we had to be attentive to the community in order to understand the context from which these boys lived and played. Finally, embedded in this work was a strong community of sport. In this section we describe how the three themes emerged through our activist approach to working with the boys.

"Demonstrations of affection are essential to the boys" - an Ethic of Care

The importance of having an ethic of care emerged as pivotal in the first coaches' work sessions.

Carla: In your opinion what do the boys like and dislike? Tell me about the boys.

Neo: The vast majority have no financial stability. In relation to the psychological, they have low self-esteem. They receive little affection. I have never met many of their parents and I realized that they do not care about the project.

Rian: I think demonstrations of affection are essential to the boys. I use to hug them. I realize this is necessary for them. Many times, I'm walking by and one of them comes and hugs me.

Daniel: Their lives are hard. We realized that they have absent families and they live in inadequate houses (Coaches' work session 1). 
The coaches offered many examples of how they showed care for the boys: "I always sit down in a circle on the floor to talk about their lives" (Daniel), "We should always talk to the boys about the possibilities like professional courses" (Rian), and "We should invite successful people from their community, to give them some examples different from a life of crime" (Maria). For these coaches sport was more than teaching skills and tactics, it was showing interest in the boys' lives outside of school, providing spaces for boys to see beyond the life of crime, and it was, according to Anthony, helping the boys learn the fortitude to persevere in the midst of adversity.

Anthony: I dress like the boys and I speak slang like them: I always try to go into their world. I'm part of their world. I try to tell them that although I was born in the slums, "favelas", I'm a teacher and I survived (Coaches' work session 7).

The coaches' conception of ethic of care could be noticed in the first work sessions, unlike the perceptions of the boys who needed more time and different ways of inquiring to assist them to talk about their conceptions. The boys started to talk when I asked them hypothetical questions like what would be their ideal coach.

Leon: The best coach in the world would be like a psychologist, someone who talks about everything. He would talk about things we like. If one of us is bothered by something, if we have a problem, this coach would talk to us.

Henri: The best coach in the world talks a lot with the players, says a lot of words of encouragement.

Noel: He would listen to us.

Leon: He would be a coach who recognizes the evolution of the athlete; he considers our progress (Youth work session 2).

We realized that the coaches' behaviors resonated with the boys' ideal coach. For the boys, a coach should be: "like a psychologist" (Leon), "[someone] who look me in the eyes" (Eduardo), and "someone who could help other kids to avoid a life of crime" (Noel). While working in socially vulnerable areas, the coaches needed to show the boys respect through knowing about and understanding their life situations - they need to know the whole child. In addition, the coaches needed to help students develop strategies for survival and to see other possibilities.

Another example was his use of a "Catholic prayer". Anthony made a decision in the middle of a very violent training session in the fourth week. The boys were fighting violently and cussing. Drug addicts were sitting on the wall using drugs, and 
Tim was whistling to stop the training session. Anthony said "Come here boys! Do you remember Coach Maria? She usually does a group hug with her athletes. I would like to do something like that with you guys. Let's stay in a circle. Let's try to touch the tip of the feet of the friend next to you. Let's try to stay together for a moment". At the end of the prayer, Anthony said: "You can be different from this, boys. You must have faith!" Anthony was showing them that religion is one way their lives could be different. Anthony was widely criticized by the coordinators of the project for deciding to do a Catholic prayer. In the next week we understood the boys' view of the prayer.

Carla: What do you think about the prayer?

Eric: $\quad$ No one has ever done that before, but we should do it.

Henri: I think it calms down the training session.

Leon: I think it is nice, but we don't need to do it every training session. It is ideal before our games.

Noel: I think the coach's talk is enough to bring us together. Each of us has a different religion.

Leon: Each of us has our own faith. I think it's cool, but we shouldn't do it every training session.

Carla: How about if you guys take the initiative in doing that. What do you think?

Leon: I think it's cool.

Eric: The unity of our team could improve because of it (youth work session 5).

Although Anthony was convinced by the coordinators to no longer use prayer in his training sessions, the boys decided to take the initiative and pray before the games. Anthony willing risked criticism because, in that moment, he thought he was offering the boys something that they could use in their lives, and that was more important than someone telling him he shouldn't do it. They wanted/needed that prayer in that time and place, and Anthony let the boys proceed rather than to tell them they couldn't pray because of some 'proper' standard against bringing religion into the training sessions.

"I don't like the drug addict and the smell of the open canals next to the soccer field" an Attentiveness to the Community:

Carla: What would you change in your training sessions, guys?

Eduardo: I would change some of the field structures. I would put in synthetic grass and build another field in the neighbouring abandoned lot. I would close these canals in front of here. We would have perfect grass. I'd build a changing room like they have in the Santos-FC: with TV and hydro massage. Finally, I would make a real bench with a cover so the balls wouldn't hit the roof of our houses (Youth work session 3). 
Attentiveness to the Community was the second element to emerge as important when working with boys from vulnerable backgrounds. This emerged during conversations with the boys about barriers to engaging in sport. In the beginning I thought that the boys were suggesting huge changes in the project, like an expensive dressing room, because they couldn't see the problems they faced. However, Kim helped me to see that the boys are going to think big before they think small. It does not mean they are not seeing the more emergent problems like skin disease or safe water to drink; these problems are embedded in the idea of expensive changing rooms.

Lack of sanitation was a barrier the boys experienced in the sports project. After several sessions, the boys started to talk about not wanting to get sick because of the dirty grass. They also talked about the smell of the open canals next to the soccer field. In the community, problems with sanitation are similar to those reported in the training sessions.

Kaio: Our field is full of pieces of wood.

Henri: Add to this, there are community games on the weekends and several people throw cans of beer on our field. That is why our training it is going to be always like that, a lot of garbage.

Noel: There are a lot of boys in our community with the skin disease, "bicho geográfico". They are scratching all time. It is very disgusting.

Carla: How about the barriers to play in your community? What would you change, guys?

Kaio: I think dog poo stops us from playing in the street.

Luiz: I don't like the smell of the canals. It's so bad.

Garcia: Hey guys, do you remember the day we played on a soccer field that had a lot of horse poo? Sometimes, my soccer shoes were covered in horse poo.

Carla: Oh my God! Are you kidding? Did you play on that field?

Garcia: Of course, we played (Youth work session 5).

The poor physical conditions often caused the boys to develop a "skin disease" from playing in the grass. The lack of "clean toilets and water" and the "smell of the open canals" next to the soccer field were also difficult for the boys to negotiate.

Safety was the biggest community concern for the boys. The problems were not just in the community around the field, they were present on the soccer field. A big issue for the boys was the presence of drug addicts.

Carla: What would you change about your community, boys?

Breno: The drug trafficking.

Noel: I do not like the drug addicts. 
Eric: Sometimes the environment is bad because of those crazy guys: the junkies.

Carla: Are there many junkies in your neighbourhood?

Noel: There are many, many!

David: People who say things that don't make any sense like Bebeto.

Gobel: I am happy that Crack has not been sold in our neighbourhood yet. There would be more junkies here.

Eric: $\quad$ The Crack addicts are crazy (Youth work session 3).

Safety was a constant concern for the boys given their sessions took place with drug dealers and users present. Even with the presence of the drug dealers, the boys expressed fear of the police: "I cannot play on the street because of the attitudes of the police" (Kaio), "If you are playing on the street, the police come and inspect you. They have huge guns" (Garcia). In communities where you have drug trafficking in charge, violence is present and seems normal, as reported by the coaches.

Rian: I think that at least one person a week is killed in that neighbourhood.

Daniel: I remember I was watching a game and there were two guys sitting on the wall and talking: "Did you see who was killed yesterday? Jorge was killed. I was almost shot in the back instead of Jorge?" These guys spoke as if this situation was trivial.

Rian: The truth is that we are not safe in the training sessions. We cannot prevent people from entering the soccer field. The drug addicts come to see our training sessions.

Anthony: This is normal for me, too. I did not realize the severity of this. In my childhood, it was the same. I use to play with drug addicts (Coaches' work session 11).

Another barrier the boys experienced was lack of opportunities to play. The boys spent four hours in school. So, for the rest of the day, the boys were idle. Opportunities to play sports were scarce in that community. The neighborhood did not have public spaces for the boys to enjoy. However, the boys often trespassed onto private property to play soccer.

Carla: The coaches told me there is a hierarchy in the places you use to play. For example, there is someone in charge. They said usually an older guy.

Kaio: I could kill that guy. The street is public. Where I live there is a soccer field and the drug dealers take care it, but anyone can play.

Garcia: We played at MNascimento and also on the field of an important soccer club in town.

Carla: Do you have permission to play in those places?

Henry: We just jump the wall. (Youth work session 4). 
The boys have often invaded our own soccer field by jumping the wall to play. Part of the wall was broken to facilitate their use on the days there were no training sessions. In addition, there was a tunnel at the end of the field that, according to the boys, ended in the middle of the slum.

To address youth in that community, it was essential to be aware of the problems that they encountered playing sports in order to make possible their local action.

\section{"We could bring people from the community to help the boys to see other possibilities" - a Community of Sport:}

The final element that emerged as important to this project was having a community of sport. This emerged in the work sessions where we brainstormed ways we could help the boys to see other opportunities. It happened mainly in coaches' work session 8 when we read the boys' funk songs they created. I had asked the boys to select parts of funk songs they liked and that represented their community. The lyrics described severe problems in their community: "I had no bathroom", "I had nothing to eat", "I'm preparing for the worst", "I may be arrested or may be killed". The lyrics of the funk songs showed a lack of opportunities.

Carla: I was wondering what you think the boys tried to tell us with these lyrics.

Rian: $\quad$ These lyrics are powerful.

Daniel: They are saying they have a lack of choices in their lives.

Maria: They know that a life of crime does not pay, but they are saying that there is a lack of opportunities

Rian: They report starving, living in poor conditions.

Maria: They are saying they need to fight to get money for food. They also fight becoming addicts and choosing a life of crime. They are in conflict.

Carla: How do you think we can help them to see other possibilities beyond a life of crime?

Rian: There is something we always talked about but haven't put into practice: the professional courses, for example courses to work at the port. They could continue playing soccer with us after they are 15 years old if they are doing these courses.

Anthony: I think it would be a partnership with schools would be necessary. In addition, the family should actively participate in our project.

Rian: We could also bring people from the community to speak about a successful life. Bring own experience of community to the boys. 
Maria: People from the community might also help us to get the drug addicts to leave the field during the training sessions (Coaches' work session 8).

From the coaches' point of view, it was necessary to bring people together to make changes in that complex environment. The boys also agreed with that.

Carla: You said the biggest barriers were the drug addicts and your behavior. Now I wanted to know what we could do about it?

Kaio: We can put security out front

Petro: And put up a wall for protection

Henri: We can arrange a time for them to consume. Talk to them about not using drugs while we are training. Tim or Newton could do that. (Youth work session 5).

Henri: We can also improve the football field. I even talked to my dad and he has a friend who works with gardening and he said it's no use putting sand on the football field (Youth work session 9).

The coaches agreed that the kids, the parents, school and people from the community all together should try to make a safe environment for the boys and to create opportunities for them to see other possibilities for their lives. In the boys' view, the community leaders could convince the drug dealers to not use drugs during the training sessions and parents could help to fix the problems in the soccer field.

When brainstorming ways to show the boys other opportunities, the coaches and the boys suggested that a community of sport would be necessary. To build a community of sport it was necessary for someone to be a facilitator or mediator between and with the youth and the coaches. This mediator needs to understand that all kinds of knowledge are important for collective action. Designing sport programs for youth from socially vulnerable backgrounds it was necessary to create times for the youth to see other possibilities and this required a collective action on the part of the community.

\section{Discussion and Conclusion}

In this paper we have proposed an activist approach to working with boys from socially vulnerable backgrounds in order to understand what facilitated and hindered the boys' engagement in sport. Three things emerged as key features through this process. 
First, all involved in the project worked from an ethic of care which meant that the coaches' role was showing interest in and respect for the boys' lives outside of soccer. For Paulo Freire's pedagogy of the oppressed, care and commitment are crucial aspects (Freire, 1987; Gadotti, 1996). Freire opposed the ideological straightjacket of teaching and learning as being emotionally neutral; for him it is impossible to teach without the courage to love (Fischman, 2009; Freire, 1987). Second, to address youth in this community, it was also essential to be aware of the problems that they encountered playing sports, expressed in the theme attentiveness to the community. The understanding and commitment of the youths' life situations is the road to "conscientization" - learners engage in a form of critical thinking about their situation, making possible their local action (Freire, 1987; Gadotti, 1996). Third, when designing sport programs for youth from socially vulnerable backgrounds it is required a collective action on the part of the community - a community of sport. Although we have observed an increase of activist research in general education and with girls in physical education, studies of sport programs have mainly focused on prescription and control of youth's behaviors (Lawson, 2005; Spaaij \& Jeanes, 2012). We believe that boys' engagements in sport can become a vehicle for consciencization because it is through the effort required by this engagement that the boys began to work together and to work with their coaches, and to understand why an ethic of care, an attentiveness to the community, and a community of sport are crucial to overcoming their vulnerability. This dearth of activist work highlights the necessity to develop this approach with youth from socially vulnerable backgrounds in sport contexts.

In all of this process of working we used an activist approach that embedded student-centered pedagogy alongside inquiry-based education centered in action (Oliver \& Oesterreich, 2013). This is a way of working that considered the active participation of young people (the boys) as being of equal importance to the voice of the adults (the coaches and the researcher), requiring a collaborative construction between all involved (Cammarota \& Fine, 2008; Cochran-Smith \& Lytle, 2009; Cook-Sather, 2006; Freire, 1987). When students are taken seriously and attended to as knowledgeable participants in important conversations, they feel empowered and motivated to participate constructively in their education (Cook-Sather, 2002). We conclude that sports programs should embody an activist approach to better serve youth from socially vulnerable backgrounds (Freire, 1987, 1996). 
This process was not without challenge however. Throughout the study we encountered three main challenges. The first challenge involved finding ways to assist the boys in naming their experiences. The boys needed time to know me (Carla), to know each other, and to find language to talk about their experiences. This is a challenge similar to many of the activist studies in physical education (Enright \& O'Sullivan, 2010, 2012; Fisette, 2013; Oliver \& Kirk, 2014). The second challenge was my lack of experience in student-centered pedagogy, and as a result my lack of trust in the process. I struggled to move from a teacher-direct approach to a student-centered approach. Structural support offered by an expert (Kim) was essential to allow me to avoid transforming my work sessions into lectures. I learned, also, that I had to be willing to live in the messiness that is part of a student-centered way of working (Cook, 2009). The last challenge was that we struggled with was in our attempts to not privilege adults and/or theoretical knowledge at the expense of student knowledge. It took me a long time to understand that every kind of knowledge was important in an activist approach. To assist in this implementation process, we suggest the necessity of structural support from an expert in student-centered pedagogy and inquiry-based education centered in action, especially for beginning teachers.

In the context of sports, existing pedagogical models have tended to follow a traditional approach that for the most part does not consider young peoples' voice or community participation (Hartmann \& Kwauk, 2011; Haudenhuyse et al., 2012). Unlike this conventional approach to working within pedagogical models, this study aimed to explore an activist way of working that considered sport as an opportunity for youths' engagement in a collaborative way of working. Through student-centered pedagogy and inquiry-based education centered in action, three key features of the intervention emerged in our fieldwork (an ethic of care, an attentiveness to the community and a community of sport). We speculate that these features together might be developed further to form a prototype pedagogical model for working with youth from socially vulnerable backgrounds that is consistent with an activist approach. In order to work with youth from socially vulnerable backgrounds, we think that these features may be essential and critical, for a program that aims to empower youth. Areas for future study may be to test these ideas in practice to develop then as a specific approach to working with youth from socially vulnerable backgrounds. 


\section{References}

Abramovay, M., Castro, M., Pinheiro, L., Lima, F., \& Martinelli, C. (2002). Juventude, violência e vulnerabilidade social na América Latina: desafios para políticas pública [Young people, violence and social vulnerability in Latin America: challenges for public policy]. Brasília: UNESCO.

Anzaldúa, G. (2007). Borderlands - La Frontera: The New Mestiza (3th ed.). San Francisco: Aunt Lute Books.

Bovill, C., Cook-Sather, A., \& Felten, P. (2011). Students as co-creators of teaching approaches, course design and curricula: Implications for academic developers. International Journal for Academic Development, 16(2), 133-145. doi: 10.1080/1360144X.2011.568690

Brasil. (2013). Decreto $n^{0} 8.166$, de 23 de Dezembro de 2013. Regulamenta a Lei $n^{0}$ 12.382, de 25 de fevereiro de 2011, que dispõe sobre o valor do salário mínimo e a sua política de valorização de longo prazo [Law number 12.382 of February 25, 2011, which which establishes the minimum wage]. Diário Oficial, Brasília, DF.

Burnett, C. (2013). The "uptake" of a sport-for-development programme in South Africa. Sport, Education and Society, 1-19. doi: 10.1080/13573322.2013.833505

Cammarota, J., \& Fine, M. (2008). Revolutionizing Education: Youth Participatory Action Research in Motion. New York and London: Routledge.

Casey, A. (2014). Models-based practice : great white hope or white elephant? Physical Education and Sport Pedagogy, 19(1), 18-34. doi:

10.1080/17408989.2012.726977

Coalter, F. (2005). The social benefits of sport: An overview to inform the community planning process. (Report No. 98). Retrieved from Name website:

http://www.sportni.net/sportni/wp-

content/uploads/2013/03/the_social_benefits_of_sport_an_overview_to_inform_th e_community_planning_process.pdf

Coalter, F., Allison, M., \& Taylor, J. (2000). The role of sport in regenerating deprived urban areas. The Scottish Executive Central Research. Retrieved from Name website: http://www.gov.scot/Publications/2000/09/6903/File-1

Cochran-Smith, M., \& Lytle, S. L. (2009). Inquiry as Stance: Practitioner Research for the Next Generation. New York: Teachers College Press.

Collins, P. H. (2000). Black Feminist Thought: Knowledge, Consciousness, and the Politics of Empowerment. New York: Routledge.

Cook, T. (2009). The purpose of mess in action research: building rigour though a messy turn. Educational Action Research, 17(2), 277-291. doi:10.1080/09650790902914241 
Cook-Sather, A. (2002). Authorizing Students' Perspectives : Toward Trust, Dialogue, and Change in Education. Educational Researcher, 31(4), 3-14. doi: 10.3102/0013189X031004003

Cook-Sather, A. (2006). Sound, Presence, and Power: "Student Voice" in Educational Research and Reform. Curriculum Inquiry, 36(4), 359-390. doi:10.1111/j.1467873X.2006.00363.x

Enright, E., \& O’Sullivan, M. (2010). “Can I do it in my pyjamas?” Negotiating a physical education curriculum with teenage girls. European Physical Education Review, 16(3), 203-222. doi:10.1177/1356336X10382967

Enright, E., \& O’Sullivan, M. (2012). 'Producing Different Knowledge and Producing Knowledge Differently': Rethinking Physical Education Research and Practice through Participatory Visual Methods. Sport, Education and Society, 17(1), 35-55. doi: $10.1080 / 13573322.2011 .607911$

Fine, M. (2007). Feminist designs for difference. In S.N. Hesse-Biber (Ed.), Handbook of Feminist Research: theory and practice. (pp. 613-619). London: Sage Publication.

Fischman, G. (2009). Un/Taming Freire's Pegagogy of the Opressed. In Michael Apple, Wayne Au, Luis Armando Gandin. The Routledge International Handbook of Critical Education (pp. 332-339). New York: Routledge.

Fisette, J. L. (2013). “Are you listening?”: adolescent girls voice how they negotiate self- identified barriers to their success and survival in physical education. Physical Education and Sport Pedagogy, 18(2), 184-203. doi: 10.1080/17408989.2011.649724

Fisette, J. L., \& Walton, T. A. (2014). 'If You Really Knew Me' ... I am empowered through action. Sport, Education and Society, 19(2), 131-152. doi: $10.1080 / 13573322.2011 .643297$

Fitzpatrick, K. (2013). Critical Pedagogy, Physical Education and Urban Schooling. New York: Peter Lang International Academic Publishers.

Fonseca, F. F., Sena, R. K., Santos, R. L., Dias, O. V., \& Costa, S. M. (2013). As vulnerabilidades na infância e adolescência e as políticas públicas Brasileiras de intervenção [The vulnerabilities in childhood and adolescence and the Brazilian public policy intervention]. Revista Paulista de Pediatria, 31(2), 258-264. doi:10.1590/S0103-05822013000200019

Foster-Fishman, P. G., Law, K. M., Lichty, L. F., \& Aoun, C. (2010). Youth ReACT for Social Change: a method for youth participatory action research. American Journal of Community Psychology, 46(1-2), 67-83. doi:10.1007/s10464-010-9316-y

Fox, M., \& Fine, M. (2013). Accountable to Whom? A Critical Science Counter-story about a City that Stopped Caring for its Young. Children \& Society, 27(4), 321335. doi:10.1111/chso.12031 
Freire, P. (1987). Pedagogia do Oprimido [Pedagogy of the oppressed] (17th ed.). Rio de Janeiro: Paz e Terra.

Freire, P. (1996). Pedagogia da autonomia: saberes necessários a prática educativa [Pedagogy of autonomy: necessary knowledge for educational practice]. São Paulo: Paz e Terra.

Gadotti, M. (1996). Paulo Freire: uma biobibliografia [Paulo Freire: a biobibliography]. São Paulo: Cortez Editora.

Greene, M. (2000). Imagining futures : the public school and possibility. Journal of Curriculum Studies, 32(2), 267-280. doi: 10.1080/002202700182754

Hartmann, D., \& Kwauk, C. (2011). Sport and Development: An Overview, Critique, and Reconstruction. Journal of Sport \& Social Issues, 35(3), 284-305.

doi:10.1177/0193723511416986

Haudenhuyse, R., Theeboom, M., \& Coalter, F. (2012). The potential of sports-based social interventions for vulnerable youth: implications for sport coaches and youth workers. Journal of Youth Studies, 15(4), 37-41. doi:

$10.1080 / 13676261.2012 .663895$

Hellison, D. (2000). Youth Development and Physical Activity: Linking Universities and Communities. Illinois: Human Kinetics.

Hill-Collins, P. (2000). Black Feminist Thought: Knowledge, Consciousness, and the Politics of Empowerment. New York: Routledge.

Kelly, L. (2011). 'Social inclusion' through sports-based interventions? Critical Social Policy, 31(1), 126-150. doi:10.1177/0261018310385442

Kirk, D. (2004). Framing quality physical education: the elite sport model or Sport Education? Physical Education \& Sport Pedagogy, 9(2), 185-195. doi: $10.1080 / 1740898042000294985$

Kirk, D. (2013). Educational value and models-based practice in physical education. Educational Philosophy and Theory, 45(9), 973-986. doi:10.1080/00131857.2013.785352

Lawson, H. A. (2005). Empowering people, facilitating community development, and contributing to sustainable development: The social work of sport, exercise, and physical education programs. Sport, Education and Society, 10(1), 135-160. doi: 10.1080/1357332052000308800

McDonald, B. (2014). Coaching Whiteness: Stories of 'Pacifica Exotica' in Australian High School Rugby. Sport, Education and Society, 1-18. doi: 10.1080/13573322.2014.935318 
McEvoy, E., MacPhail, A., \& Enright, E. (2015). Physical activity experiences of young people in an area of disadvantage: "there"s nothing there for big kids, like us'. Sport, Education and Society, 1-15. doi:10.1080/13573322.2014.994176

Mcintyre, A. (2000). Constructing Meaning About Violence, School, and Community: Participatory Action Research with Urban Youth. The Urban Review, 32(2), 123154. doi: 10.1023/A:1005181731698

Mirra, N., Morrell, E. D., Cain, E., Scorza, D. A., \& Ford, A. (2013). Educating for a Critical Democracy: Civic Participation Reimagined in the Council of Youth Research. Democracy \& Education, 21(1), 1-10. Retrieved from http://democracyeducationjournal.org/home/vol21/iss 1/3

Misztal, B. A. (2011). The Challenges of Vulnerability: In search of strategies for a less vulnerable social life. United Kingdom: Palgrave Macmillan Ltd.

Oliver, K. L. (2001). Images of the Body from Popular Culture: Engaging Adolescent Girls in Critical Inquiry. Sport, Education and Society, 6(2), 143-164. doi: $10.1080 / 13573320120084245$

Oliver, K. L., \& Kirk, D. (2014). Towards an activist approach to research and advocacy for girls and physical education. Physical Education \& Sport Pedagogy, 1-15. doi:10.1080/17408989.2014.895803

Oliver, K. L., \& Oesterreich, H. A. (2013). Student-Centered Inquiry as Curriculum as a Model for Field Based Teacher Education. Journal of Curriculum Studies, 1-24. doi: $10.1080 / 00220272.2012 .719550$

Petit, M. (2009). A Arte de Ler - Ou Como Resistir à Adversidade [The Art of Reading or How to Resist the Adversity]. São Paulo: Editora 34.

Hooks, B. (2000). Feminism Is for Everybody: Passionate Politics. Cambridge: South end Press.

Sandford, R., \& Duncombe, R. (2011). Disaffected youth in physical education and youth sport. In K. Armour (Ed.), Sport Pedagogy: An Introduction for Teaching and Coaching. (pp. 165-189). London: Routledge.

SEADE. FUNDAÇÃO SISTEMA ESTADUAL DE ANÁLISE DE DADOS. (2003) Índice Paulista de Vulnerabilidade Social [Index of Social Vulnerability in Sao Paulo State]. Retrieved from http://www.seade.gov.br/projetos/ipvs/consult_padrao.php

SEADE. FUNDAÇÃO SISTEMA ESTADUAL DE ANÁLISE DE DADOS (2010). Índice Paulista de Vulnerabilidade Social [Index of Social Vulnerability in Sao Paulo State]. Retrieved from http://www.iprsipvs.seade.gov.br/view/pdf/ipvs/metodologia.pdf

Shor, I. (1992). Empowering education: Critical teachingfor social change. Chicago: The University of Chicago Press 
Smyth, J., Mooney, A., \& Casey, M. (2011). Where has class gone? The pervasiveness of class in girls' physical activity in a rural town. Sport, Education and Society, 19(1), 1-18. doi:10.1080/13573322.2011.619525

Spaaij, R., \& Jeanes, R. (2012). Education for social change? A Freirean critique of sport for development and peace. Physical Education \& Sport Pedagogy, 1-16. doi: $10.1080 / 17408989.2012 .690378$

Vandermeerschen, H., Vos, S. \& Scheerder, J. (2013). Who's Joining the Club? Participation of Socially Vulnerable Children and Adolescents in Club-Organised. Sports. Sport, Education and Society, 1-18. doi: 10.1080/13573322.2013.856293

Wright, D. E., \& Mahiri, J. (2012). Literacy Learning Within Community Action Projects for Social Change. Journal of Adolescent \& Adult Literacy, 56(2), 123 131. doi: 10.1002/JAAL.00113

Yang, K. W. (2009). Mathematics, critical literacy, and youth participatory action research. New Direction for Youth Development, (123), 99-119. doi: $10.1002 / y d .317$ 